Louisiana State University

LSU Digital Commons

Faculty Publications

Department of Geology and Geophysics

3-27-2015

\title{
Human impact overwhelms long-term climate control of weathering and erosion in southwest China
}

\author{
Shiming Wan \\ Institute of Oceanology Chinese Academy of Sciences \\ Samuel Toucanne \\ IFREMER Institut Francais de Recherche pour l'Exploitation de la Mer \\ Peter D. Clift \\ Louisiana State University \\ Debo Zhao \\ Institute of Oceanology Chinese Academy of Sciences \\ Germain Bayon \\ IFREMER Institut Francais de Recherche pour l'Exploitation de la Mer
}

See next page for additional authors

Follow this and additional works at: https://digitalcommons.Isu.edu/geo_pubs

\section{Recommended Citation \\ Wan, S., Toucanne, S., Clift, P., Zhao, D., Bayon, G., Yu, Z., Cai, G., Yin, X., Révillon, S., Wang, D., Li, A., \& Li, T. (2015). Human impact overwhelms long-term climate control of weathering and erosion in southwest China. Geology, 43 (5), 439-442. https://doi.org/10.1130/G36570.1}

This Article is brought to you for free and open access by the Department of Geology and Geophysics at LSU Digital Commons. It has been accepted for inclusion in Faculty Publications by an authorized administrator of LSU Digital Commons. For more information, please contact ir@lsu.edu. 


\section{Authors}

Shiming Wan, Samuel Toucanne, Peter D. Clift, Debo Zhao, Germain Bayon, Zhaojie Yu, Guanqiang Cai, Xuebo Yin, Sidonie Révillon, Dawei Wang, Anchun Li, and Tiegang Li 
Geology

June 2015, Volume 43 Issue 5 Pages 439-442

http://dx.doi.org/10.1130/G36570.1

http://archimer.ifremer.fr/doc/00266/37754/

(c) 2015 Geological Society of America. For permission to copy, contact

editing@geosociety.org.

\title{
Human impact overwhelms long-term climate control of weathering and erosion in southwest China
}

\author{
Wan S. ${ }^{1, *}$, Toucanne Samuel ${ }^{2}$, Clift P. D. ${ }^{3}$, Zhao D. ${ }^{1}$, Bayon Germain ${ }^{2,4}$, Yu Z. ${ }^{5}$, Cai G. ${ }^{6}$, \\ Yin Xiaoming ${ }^{1}$, Revillon Sidonie ${ }^{7}$, Wang D. ${ }^{1}$, Li A. ${ }^{1}$, Li T. ${ }^{1}$
}

${ }^{1}$ Key Laboratory of Marine Geology and Environment, Institute of Oceanology, Chinese Academy of Sciences, Qingdao 266071, China

2 IFREMER, Unité de Recherche Géosciences Marines, BP70, 29280 Plouzané, France

${ }^{3}$ Department of Geology and Geophysics, Louisiana State University, Baton Rouge, Louisiana 70803, USA

${ }^{4}$ Department of Earth Sciences, Royal Museum for Central Africa, B-3080 Tervuren, Belgium

${ }^{5}$ Laboratoire IDES, UMR 8148 CNRS, Université de Paris XI, Orsay 91405, France

${ }_{7}^{6}$ Guangzhou Marine Geological Survey, Guangzhou 510760, China

7 SEDISOR/UMR 6538 "Domaines Oceaniques", IUEM, Place Nicolas Copernic, 29280 Plouzané, France

\begin{abstract}
:
During the Holocene there has been a gradual increase in the influence of humans on Earth systems. High-resolution sedimentary records can help us to assess how erosion and weathering have evolved in response to recent climatic and anthropogenic disturbances. Here we present data from a highresolution ( $75 \mathrm{~cm} / \mathrm{k}$.y.) sedimentary archive from the South China Sea. Provenance data indicate that the sediment was derived from the Red River, and can be used to reconstruct the erosion and/or weathering history in this river basin. Accelerator mass spectrometry $14 \mathrm{C}$ dating provides direct age control and reveals coherent variations in clay mineralogy, geochemistry, and terrigenous flux, indicative of strong chemical weathering and physical erosion during the mid-Holocene warm period (6400-4000 cal [calibrated] yr B.P.), followed by weakening from ca. 4000-1800 cal yr B.P., and renewed intensification since 1800 cal yr B.P.. Comparison with climatic records from China indicates that precipitation and temperature controlled both physical erosion and chemical weathering intensity before $1800 \mathrm{cal}$ yr B.P.. However, weathering proxies in the offshore sediment indicate recent increased soil erosion. We suggest that enhanced human activity (deforestation, cultivation, and mining) since the end of the Chinese Han Dynasty (220 CE) has overwhelmed the natural climatic controls on erosion in the Red River.
\end{abstract}




\section{Introduction}

Continental erosion and weathering are the key processes that shape the Earth's landscape, regulate atmospheric $\mathrm{CO}_{2}$, and control the delivery of sediments and solutes to the ocean, affecting global climate over geological time scales (Raymo and Ruddiman, 1992). In turn temperature, precipitation, and physical erosion are critical factors influencing silicate weathering (Maher, 2011; West, 2012). Most studies of silicate weathering either focus on proxy records spanning thousands to million years (Colin et al., 2006; Lupker et al., 2013; Wan et al., 2012) or modern observations from soils or rivers (Liu et al., 2007; West, 2012). In contrast, high-resolution records spanning the Holocene remain scarce (Bayon et al., 2012; Catalan et al., 2014; Hu et al., 2013). This time period is of particular interest for paleoclimate studies because it not only represents the most recent interglacial interval, but also one affected by anthropogenic processes (Bayon et al., 2012). Lake (Catalan et al., 2014; Shen et al., 2006) and deltaic cores (Hu et al., 2013; Li et al., 2009) have been used to reconstruct Holocene erosion and weathering rates to determine their relationship with climate and human activity. However, lake catchments are often local and delta sediment may be disturbed by reworking (Stanley and Hait, 2000). In contrast, continental slope settings experience relatively stable depositional environments and high sedimentation rates (Bayon et al., 2012). Here we report on the first, continuous, high-resolution record of Red River discharge and investigate the interplay between Holocene climate variability, human activity and erosion/weathering processes in SW China.

\section{Materials And Methods}

Core 337PC was retrieved from the Qiongdongnan Basin offshore the Red River delta, at $516 \mathrm{~m}$ water depth (Fig. 1). The area has largely been supplied by the Red River since the Late Miocene (Wang et al., 2011) and derives sediment from southeastern Tibet. Core 337PC comprises homogeneous, hemipelagic clayey silt. Ten AMS ${ }^{14} \mathrm{C}$ dates from planktonic foraminifera reveal linear sedimentation rates of $\sim 75 \mathrm{~cm} / \mathrm{kyr}$, providing a continuous, high-resolution record of continental conditions since $\sim 6400 \mathrm{yr}$ BP (Fig. 2a). Terrigenous grain-size was analyzed for 478 samples by laser particle analyzer. Clay mineralogy was determined by routine X-Ray Diffraction (XRD) analysis (Wan et al., 2012). Major and trace element concentrations were determined from 48 bulk terrigenous samples and $<2 \mu \mathrm{m}$ clay separates of 116 samples by Inductively Coupled Plasma Emission and Mass Spectrometry (ICP-AES and ICP-MS). Uncertainties were $<1 \%$ for major elements and $3 \%$ for trace elements. In order to constrain provenance, $\mathrm{Sr}$ and $\mathrm{Nd}$ isotopic compositions were determined on 12 samples, as well as four muddy river samples from Hainan (Fig. 1). The weathering of plagioclase was qualitatively evaluated by grain surface morphology using scanning electron microscopy (SEM) (Read et al., 1996). Details on methods and data are provided in the Supplementary Information (SI). 


\section{Provenance And Proxies}

The Nd isotopic composition and to a lesser extent the silicate ${ }^{87} \mathrm{Sr} /{ }^{86} \mathrm{Sr}$ can be used as tracers of sediment provenance (Colin et al., 2006; Lupker et al., 2013). Figure 2b shows variations in $\varepsilon_{\mathrm{Nd}}$ versus ${ }^{87} \mathrm{Sr} /{ }^{86} \mathrm{Sr}$, with values from potential sources, indicating sediment delivery dominated by the Red River. Although $\mathrm{Sr}$ isotopes of detrital sediments show weak negative correlation $\left(R^{2}=-0.18\right)$ with the coarse grain-size fraction (Figs. S1-2), grain-size does not exert a significant influence on provenance proxies because variations in ${ }^{87} \mathrm{Sr} /{ }^{86} \mathrm{Sr}$ values $(0.722120-0.723993)$ are very small compared with those seen in potential source regions and fall well within the range seen in the Red River (Fig. 2b). In contrast, Nd isotopes are not biased by grain-size (Fig. S2). Both $\mathrm{Nd}$ isotopes and $\mathrm{La} / \mathrm{Th}$ ratios display no significant temporal trend during the Holocene (Fig. 3), suggesting that there is no major change in source during that time. We conclude that this sequence effectively records the Holocene sediment discharge of the Red River, and hence can be used to reconstruct environmental changes in this basin.

We use kaolinite/illite and the chemical index of alteration (CIA; Nesbitt and Young, 1982 ) of the $<2 \mu \mathrm{m}$ clay fraction to reconstruct chemical weathering intensity through time, which gives a quantitative measure of chemical alteration by constraining the loss of labile $\mathrm{Na}, \mathrm{Ca}$, and $\mathrm{K}$ relative to stable Al. We define the term "chemical weathering intensity' here as 'the degree of chemical alteration of the soil products relative to host rocks in the drainage area due to silicate weathering'. Kaolinite is formed in soils developed in regions with warm, humid climates and good drainage conditions, whereas illite is the product of physical erosion from bedrock or formed by weathering of feldspar and micas under moderate hydrolysis conditions (Chamley, 1989). With intensification of chemical weathering in the basin, further degradation of illite to kaolinite would result in a higher kaolinite to illite ratio (Liu et al., 2007; Wan et al., 2012). Terrigenous mass accumulation offshore delivered from rivers can also represent a proxy of accelerated soil erosion onshore (Clift et al., 2014; Wan et al., 2012).

In addition to chemical weathering and provenance changes, other factors may influence the sedimentary mineralogy and geochemistry, such as hydraulic sorting by oceanic currents, sea-level change, as well as post-depositional diagenesis. The absence of authigenic minerals observed by XRD or SEM indicates negligible diagenesis, consistent with the shallow burial and high sedimentation rates. Hydrologic sorting does not appear to have significant influence on either the kaolinite/illite ratio or the CIA of the $<2 \mu \mathrm{m}$ fraction (Fig. S2). Because we have a single dominant source significant effects from mixed sources due to changing currents can be excluded. No reversed ${ }^{14} \mathrm{C}$ age or turbidite-like deposit was observed, suggesting insignificant reworking of sediments on the shelf. Sea-level has remained stable over the studied period (Siddall et al., 2003)(Fig. 3), so it is not expected to have had any influence on sediment composition at Core 337PC. The lack of correlation between terrigenous grain-size and sea-level on one hand and terrigenous MAR, kaolinite/illite, and CIA 
values on the other (Figs. 3 and S2) strongly suggests that these latter proxies do not reflect changes in transport processes, but instead can be used to reconstruct weathering/erosion onshore. Finally, soil residence time in the river basin is crucial for the interpretation of weathering proxies in offshore sediments. Estimates for denudation rates in the Red River basin range $\sim 0.4-0.7 \mathrm{~mm} / \mathrm{yr}$, based on sediment yield, and $\sim 0.4-8 \mathrm{~mm} / \mathrm{yr}$, as calculated by ${ }^{10} \mathrm{Be}$ data from the region (Henck et al., 2011). According to the relationship between denudation rate and soil time scale of Blanckenburg (2005), we estimate $\sim 200-1000 \mathrm{yr}$ for soil residence time in the Red River basin. This means that the offshore weathering records could have a 200-1000 yr time lag between deposition and the initial chemical weathering.

\section{Climate vs Human control on EROSION/weathering}

The clay mineral and geochemical proxies reveal consistent variation since $6400 \mathrm{yr}$ BP (Fig. 3d). In general, CIA and kaolinite/illite values show that the terrigenous alteration during the Holocene can be divided into three stages: Stage 1 (6400-4000 yr BP), characterized by relatively strong weathering intensity during the mid-Holocene warm period; Stage 2 (4000-1800 yr BP), with gradually weakening weathering intensity; and finally Stage 3 (since $1800 \mathrm{yr}$ BP), with evidence for a rapid strengthening of weathering. This trend is also supported by morphological examinations of $>31 \mu \mathrm{m}$ feldspar grains using SEM (Fig. S3). Feldspar grains in sediments from Stage 3 display higher weathering class (high) compared to those from Stages 1 (medium high) and 2 (medium low). Similar variation is also found in the erosion record, as tracked by terrigenous MAR, with high values $\left(\sim 69 \mathrm{~g} / \mathrm{cm}^{2} / \mathrm{kyr}\right)$ during Stage 1, very low values during Stage $2\left(\sim 36 \mathrm{~g} / \mathrm{cm}^{2} / \mathrm{kyr}\right)$, and high values again during Stage $3(\sim 74$ $\mathrm{g} / \mathrm{cm}^{2} / \mathrm{kyr}$ )(Fig. 3e).

In general, the long-term weathering and erosion trends during Stages 1 and 2 track the temperature in Southwest China (Hou and Fang, 2012). They also follow the decreased rainfall signal inferred from the Dongge Cave speleothem isotopic records (Fig. 3c), which is ultimately related to orbitally induced lowering of Northern Hemisphere summer solar insolation during this interval (Wang et al., 2005). Decreased physical erosion was dominated by weakening precipitation during the time. Considering the much longer time span of the study period compared to the soil residence time and stable provenance, we are confident that the general weakening of chemical alteration seen during the mid-Holocene reflects an overall change of weathering conditions in the Red River basin.

Among the rivers that drain southeastern Tibet, the Red River has the highest physical erosion rate $\left(1100 \mathrm{t} / \mathrm{km}^{2} / \mathrm{y}\right)$ and far exceeds the supply limit condition ( 100 $\left.\mathrm{t} / \mathrm{km}^{2} / \mathrm{y}\right)($ West, 2012). Under this weathering-limited regime, chemical weathering is incomplete, incongruent and dependent on the kinetics of silicate mineral dissolution reactions, as regulated by temperature, runoff and vegetation (Maher, 2011; West, 2012). This mechanism is demonstrated by close coupling between continental silicate 
weathering, physical erosion, and climatic forcing during the middle Holocene in the Red River basin.

A similar decreased Holocene weathering trend is also found in delta of the Pearl River in South China (Hu et al., 2013), and the Congo River in Central Africa (Bayon et al., 2012), as well as Redon Lake in Spain (Catalan et al., 2014), and offshore North America (Kurzweil et al., 2010) (Fig. 1). The general, global-scale weakening of silicate weathering during the middle Holocene and consequent reduced $\mathrm{CO}_{2}$ consumption correlates with rising atmospheric $\mathrm{CO}_{2}$ levels (Luthi et al., 2008) (Fig. 3g). Although the sustained and slowly-rising $\mathrm{CO}_{2}$ atm has been ascribed to anthropogenic processes as early as $6000 \mathrm{yr}$ BP (Ruddiman et al., 2011), climate change rather than human disturbance seems to have dominated continental silicate weathering at least during the middle Holocene.

Interestingly, some decoupling between climate and erosion/weathering records occurs during the late Holocene. Rapid intensification of both weathering intensity (Fig. 3d) and physical erosion (Fig. 3e) started after $1800 \mathrm{yr}$ BP (Stage 3), while both precipitation and temperature remained relatively stable between 1800 and $500 \mathrm{yr}$ BP and slightly increased after $500 \mathrm{yr}$ BP. This suggests no direct relationship between weathering/erosion and precipitation/temperature at that time. Moreover, weathering proxies including kaolinite/illite and $\mathrm{CIA}$ reached maximum values after $500 \mathrm{yr} \mathrm{BP}$ rather than during the mid Holocene, despite the fact that precipitation or temperature was significantly lower at that time than before $4000 \mathrm{yr}$ BP (Fig. 3). All the above suggest that climate alone cannot be solely responsible for the weathering/erosion changes observed since $1800 \mathrm{yr}$ BP. Because this interval is comparable to the soil residence time in the Red River basin, it is difficult to distinguish enhanced erosion of older soils from contemporaneous chemical weathering conditions. We suggest that both processes are related to stronger human activity and have contributed to the increased alteration observed in the core.

A striking feature of our results is that sulfur-related metal elements (i.e. As, $\mathrm{Pb}, \mathrm{Cu}$, Mo, W) and corresponding element enrichment factors (Fig. 3e and S4) strongly increased 2-3 times after $1800 \mathrm{yr}$ BP. Many of these elements occur together in polymetallic sulfide minerals in gold-bearing deposits. Gold mining in China's Yunnan Province dates back to the Han Dynasty, about 2000 years BP (Chen, 2001), and this activity could have released abundant sulfur-related metals into the river. In addition, smelting through burning of trees was crucial to gold extraction in ancient times. Moreover, strengthened weathering/erosion and sulfur-related metal element accumulation since $1800 \mathrm{yr}$ BP coincides with evidence for intensified agriculture and early urbanization in the Red River basin (Li et al., 2009; Shen et al., 2006)(Figs. 1 and 3f). The large-scale human migration into the lower reaches of the Red River from South China occurs after $2000 \mathrm{yr}$ BP (Li et al., 2009). Nonetheless, regardless of the exact cause of the intensified deforestation since $1800 \mathrm{yr}$ BP (Fig. 3g), the higher demand for natural resources was probably the ultimate reason for the trends 
described above. Deforestation, cultivation and mining-induced rock exposure stimulated stronger soil erosion and reworking of altered sediment from the existing weathering profile. Our data show that human impact gradually supersedes long-term climate control of erosion/weathering in the Red River basin, especially since $1800 \mathrm{yr}$ BP.

\section{Implications}

Our study provides evidence about when and how the Red River basin switched from a climate-dominated to a human-disturbed erosion/weathering pattern. One important implication of this finding is that millennial-scale changes in silicate weathering in regions with high denudation rate cannot be overlooked in the current context of global climate change and the carbon cycle. These regions may be particularly important in influencing the carbon cycle because of both high weathering flux and high sensitivity to long-term temperature-weathering feedbacks. Our study also highlights the importance of increased soil erosion, as tracked by weathering proxies in offshore sediments. This anthropogenic effect on the environment has exceeded the influence of natural climate change over the last 1.8 k.y., suggesting that the modern Red River cannot be used as modern analog for understanding controls on erosion and weathering in the geologic past.

\section{Acknowledgements}

We thank X. Shen, X. Zheng and W. Liu for their help during lab work, as well as Beta Analytic Inc for technical support on AMS ${ }^{14} \mathrm{C}$ dating. We are grateful to editor $\mathrm{E}$. Thomas, J. West, C. Colin, J.-B. Stuut, and four anonymous reviewers for their constructive comments. National Natural Science Foundation of China (41076033) funded this study.

\section{References CITED}

Bayon, G., Dennielou, B., Etoubleau, J., Ponzevera, E., Toucanne, S., and Bermell, S., 2012, Intensifying Weathering and Land Use in Iron Age Central Africa: Science, v. 335, p. 1219-1222.

Blanckenburg, F., 2005, The control mechanisms of erosion and weathering at basin scale from cosmogenic nuclides in river sediment: Earth and Planetary Science Letters, v. 237, p. 462-479.

Catalan, J., Pla-Rabes, S., Garcia, J., and Camarero, L., 2014, Air temperature-dirven $\mathrm{CO}_{2}$ consumption by rock weathering at short timescales: evidence from a Holocene lake sediment record: Geochimica et Cosmochimica Acta, v. 136, p. 67-79.

Chamley, H., 1989, Clay Sedimentology: Berlin, Springer-Verlag. 
Chen, Y., Li, Z., Wu, R., 2001, Chinese gold deposits and metallogenetic rules: Beijing, Geology Press, 465 p.

Chen, Z., 1997, Chinese population changes and climatic variations: Science Monthly, v. 335, p. 1-7.

Clift, P.D., Wan, S.M., and Blusztajn, J., 2014, Reconstructing chemical weathering, physical erosion and monsoon intensity since $25 \mathrm{Ma}$ in the northern South China Sea: A review of competing proxies: Earth-Science Reviews, v. 130, p. 86-102.

Colin, C., Turpin, L., Blamart, D., Frank, N., Kissel, C., and Duchamp, S., 2006, Evolution of weathering patterns in the Indo-Burman Ranges over the last 280 kyr: Effects of sediment provenance on $\mathrm{Sr}-87 / \mathrm{Sr}-86$ ratios tracer: Geochemistry Geophysics Geosystems, v. 7.

Goldstein, S.J., and Jacobsen, S.B., 1988, Nd and Sr isotopic systematics of river water suspended material: implications for crustal evolution: Earth and Planetary Science Letters, v. 87, p. 249-265.

Henck, A.C., Huntington, K.W., Stone, J.O., Montgomery, D.R., and Hallet, B., 2011, Spatial controls on erosion in the three rivers region, southeastern Tibet and southwestern China: Earth and Planetary Science Letters, v. 303, p. 71-83.

Hou, G., and Fang, X., 2012, Characteristics analysis and synthetical reconstruction of regional temperature series of the Holocene in China: Journal of Palaeogeography, v. 14, p. 243-252.

Hu, D.K., Clift, P.D., Boning, P., Hannigan, R., Hillier, S., Blusztajn, J., Wan, S.M., and Fuller, D.Q., 2013, Holocene evolution in weathering and erosion patterns in the Pearl River delta: Geochemistry Geophysics Geosystems, v. 14, p. 2349-2368.

Kurzweil, F., Gutjahr, M., Vance, D., and Keigwin, L., 2010, Authigenic Pb isotopes from the Laurentian Fan: changes in chemical weathering and patterns of North American freshwater runoff during the last deglaciation: Earth and Planetary Science Letters, v. 299, p. 458-465.

Lan, C.Y., Lee, C.S., Shen, J.J., Lu, C.Y., Mertzman, S.A., and Wu, T.W., 2002, Nd-Sr isotopic composition and geochemistry of sediments from Taiwan and their implications: Western Pacific Earth Sciences, v. 2, p. 205-222.

Li, Z., Saito, Y., Dang, P.X., Matsumoto, E., and Quang, L.V., 2009, Warfare rather than agriculture as a critical influence on fires in the late Holocene, inferred from northern Vietnam: Proceedings of the National Academy of Sciences of the United States of America, v. 106, p. 11490-11495.

Liu, Z., Colin, C., Huang, W., Le, K.P., Tong, S., Chen, Z., and Trentesaux., 2007, Climatic and tectonic controls on weathering in south China and Indochina Peninsula: clay mineralogical and geochemical investigations from the Pearl, Red, and Mekong drainage basins.: Geochemistry Geophysics Geosystems, v. 8, p. Q05005, doi:10.1029/2006GC001490.

Lupker, M., France-Lanord, C., Galy, V., Lave, J., and Kudrass, H., 2013, Increasing chemical weathering in the Himalayan system since the Last Glacial Maximum: Earth and Planetary Science Letters, v. 365, p. 243-252. 
Luthi, D., Le Floch, M., Bereiter, B., Blunier, T., Barnola, J.M., Siegenthaler, U., Raynaud, D., Jouzel, J., Fischer, H., Kawamura, K., and Stocker, T.F., 2008, High-resolution carbon dioxide concentration record $650,000-800,000$ years before present: Nature, v. 453, p. 379-382.

Maher, K., 2011, The role of fluid residence time and topographic scales in determining chemical fluxes from landscapes: Earth and Planetary Science Letters, v. 312, p. 48-58.

Nesbitt, H.W., and Young, G.M., 1982, Early Proterozoic climate and plate motions inferred from major element chemistry of lutites: Nature, v. 299, p. 715-717.

Raymo, M.E., and Ruddiman, W.F., 1992, Tectonic Forcing of Late Cenozoic Climate: Nature, v. 359, p. 117-122.

Read, G., Kemp, R., and Rose, J., 1996, Development of a feldspar weathering index and its application to a buried soil chronosequence in southeastern England: Geoderma, v. 74, p. 267-280.

Ruddiman, W.F., Kutzbach, J.E., and Vavrus, S.J., 2011, Can natural or anthropogenic explanations of late-Holocene $\mathrm{CO}_{2}$ and $\mathrm{CH}_{4}$ increases be falsified?: Holocene, v. 21, p. $865-879$.

Schimanski, A., 2002, Holocene sedimentation on the Vietnamese shelf: from source to sink [Ph.D thesis]: Kiel, Kiel University.

Shen, J., Jones, R.T., Yang, X.D., Dearing, J.A., and Wang, S.M., 2006, The Holocene vegetation history of Lake Erhai, Yunnan province southwestern China: the role of climate and human forcings: Holocene, v. 16, p. 265-276.

Siddall, M., Rohling, E.J., Almogi-Labin, A., Hemleben, C., Meischner, D., Schmelzer, I., and Smeed, D.A., 2003, Sea-level fluctuations during the last glacial cycle: Nature, v. 423, p. 853-858.

Stanley, D.J., and Hait, A.K., 2000, Deltas, radiocarbon dating, and measurements of sediment storage and subsidence: Geology, v. 28, p. 295-298.

Wan, S.M., Clift, P.D., Yu, Z., Li, A., and Li, T., 2012, Tectonic and climatic controls on long-term silicate weathering in Asia since 5 Ma: Geophysical Research Letters, v. 39, p. doi:10.1029/2012GL052377.

Wang, Y.J., Cheng, H., Edwards, R.L., He, Y.Q., Kong, X.G., An, Z.S., Wu, J.Y., Kelly, M.J., Dykoski, C.A., and Li, X.D., 2005, The Holocene Asian monsoon: Links to solar changes and North Atlantic climate: Science, v. 308, p. 854-857.

Wang, Y.M., Xu, Q., Li, D., Han, J.H., Lu, M., Wang, Y.F., Li, W.G., and Wang, H.R., 2011, Late Miocene Red River submarine fan, northwestern South China Sea: Chinese Science Bulletin, v. 56, p. 1488-1494.

Wei, G.J., Liu, Y., Ma, J.L., Xie, L.H., Chen, J.F., Deng, W.F., and Tang, S., 2012, Nd, $\mathrm{Sr}$ isotopes and elemental geochemistry of surface sediments from the South China Sea: Implications for Provenance Tracing: Marine Geology, v. 319, p. 21-34.

West, A.J., 2012, Thickness of the chemical weathering zone and implications for erosional and climatic drivers of weathering and for carbon-cycle feedbacks: Geology, v. 40, p. 811-814. 


\section{Figures}

Fig. 1. Locations of geographic features and terrestrial and marine records mentioned in the text. The global map insert shows other related cores cited in this study. The red dashed line shows the Red River submarine deposition system (Wang et al., 2011).

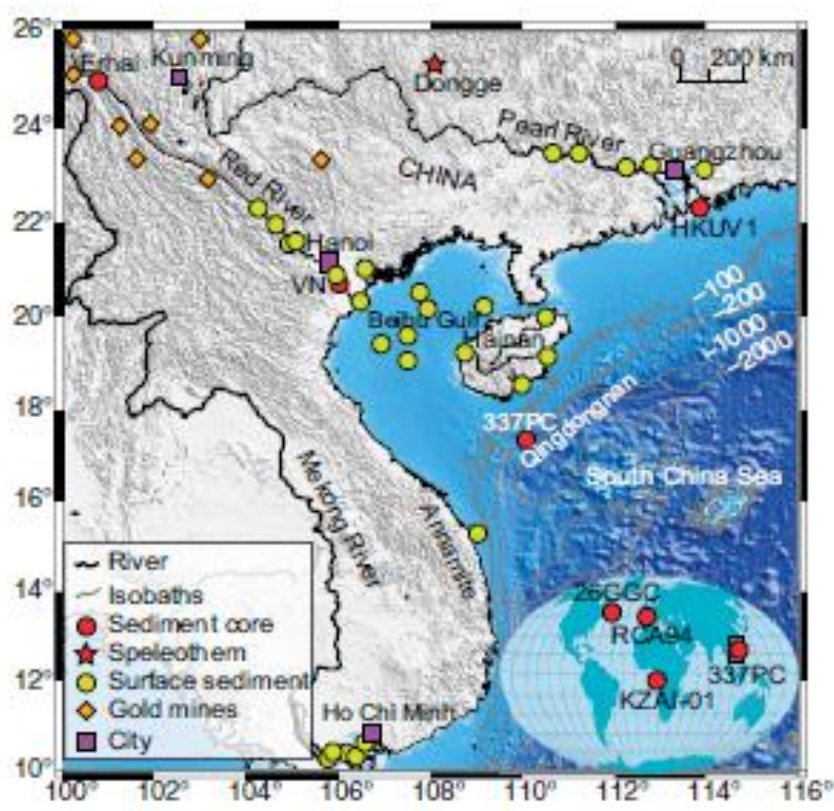

Fig. 2. (a) Depth-age profile, and (b) sediment provenance discrimination diagram. Ten AMS ${ }^{14} \mathrm{C}$ dates of planktonic foraminfer samples are shown with an uncertainty of $2 \delta$. For comparison, Sr-Nd isotopes data of sediments from the Pearl, Red and Mekong Rivers (Liu et al., 2007), Beibu Gulf (Wei et al., 2012), Annamite Range (Schimanski, 2002), Taiwanese Rivers (Lan et al., 2002), Luzon (Goldstein and Jacobsen, 1988) and Hainan rivers (this study) are plotted.
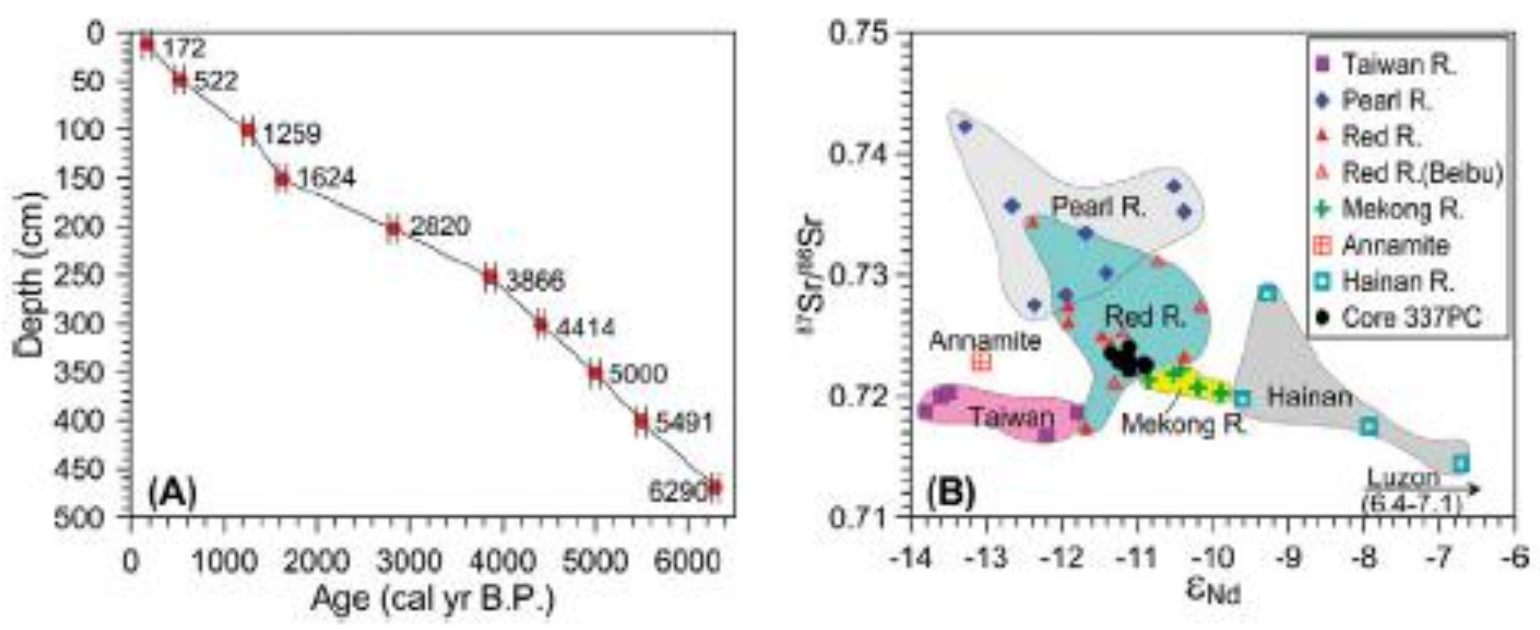
Fig. 3. Comparison of Core 337PC records with other records since $6400 \mathrm{yr}$ BP. (a) Sea level change (Siddall et al., 2003) (black line) and terrigeous mean grain-size at Core 337PC (raw data, gray line; 25 points running average, purple line); (b) La/Th ratio (brown circle) and $\mathrm{Nd}$ isotopic composition (pink circle) with an uncertainty of $2 \delta$ at the study core; (c) Temperature anomaly in SW China (Hou and Fang, 2012) (orange line) with uncertainty (yellow band) and the summer monsoon proxy of stalagmite $\delta^{18} \mathrm{O}$ at Dongge Cave (Wang et al., 2005) (raw data, blue line; 35 points average, black); (d) CIA of clay fraction (magenta diamond), kaolinite/illite (green circle) at Core 337PC; (e) Enrichment factor of As (orange diamond) and terrigenous flux (brown circle) at Core 337PC; (f) Charcoal record of Core VN in the Red River delta (Li et al., 2009) (black bars) and pollen record in the Lake Erhai (Shen et al., 2006) (blue line); (g) Chinese population (Chen, 1997) (red) and atmospheric $\mathrm{CO}_{2}$ level (Luthi et al., 2008) (blue). The gray band indicates the time period dominated by human activity.

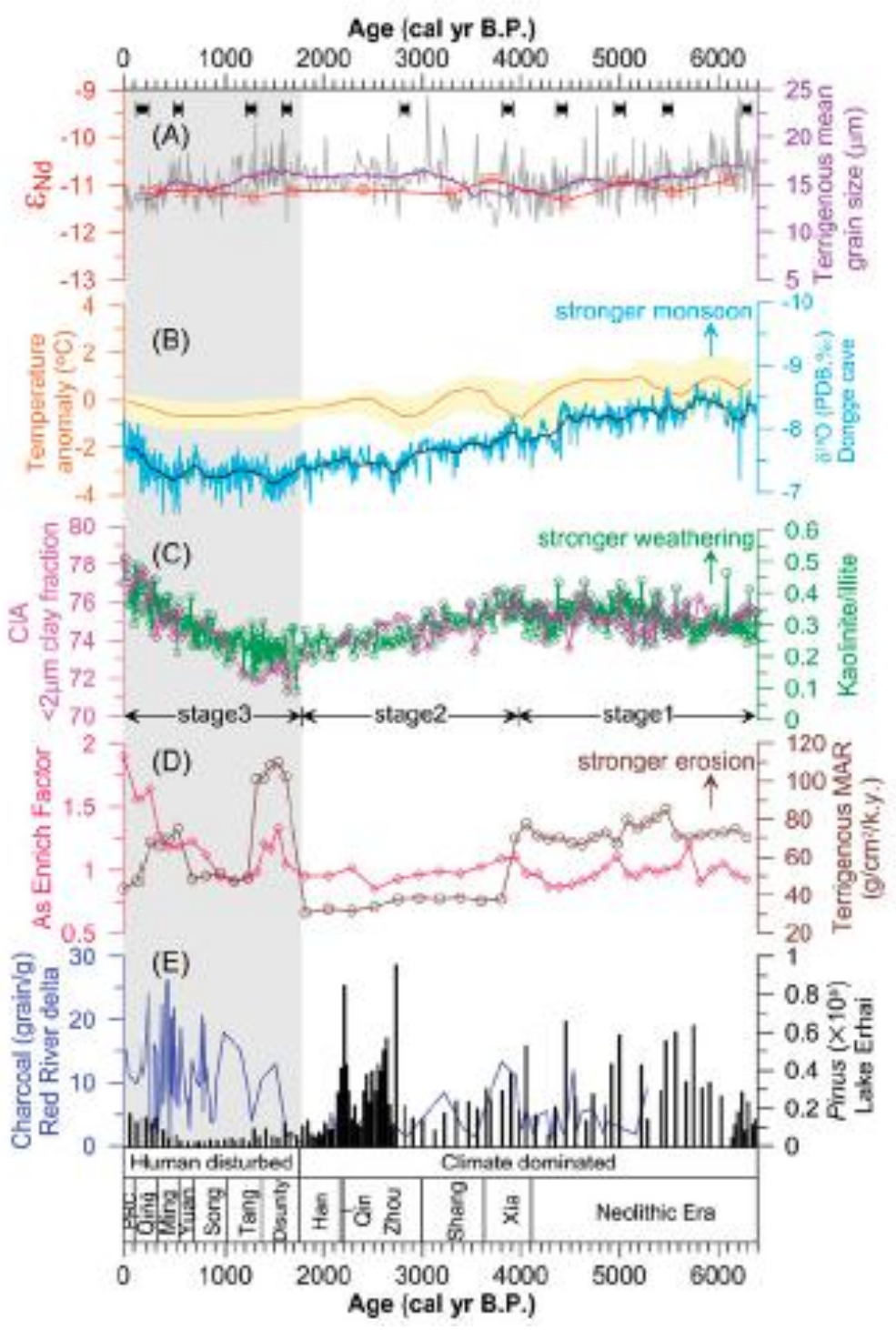

